\title{
USULAN PENENTUAN WAKTU BAKU PROSES RACKING PRODUK AMPLIMESH DENGAN METODE JAM HENTI PADA DEPARTEMEN POWDER COATING
}

\author{
YURI DELANO REGENT MONTORORING \\ Program Studi Teknik Industri \\ Fakultas Teknik - Universitas Bhayangkara Jakarta Raya \\ Email:yuri.delano@dsn.ubharajaya.ac.id
}

\begin{abstract}
ABSTRAK
Untuk meningkatkan kapasitas produksi diperlukan adanya sistem kerja yang mendukung. Salah satu cara yang bisa dipakai yaitu membakukan waktu proses dari pekerjaan khususnya proses racking produk amplimesh pada departemen powder coating. Dengan melakukan penentuan waktu baku diharapkan keluaran produksi bisa ditingkatkan. Metode yang digunakan dalam penelitian ini ialah metode jam henti, dimana pengambilan sampel data waktu dilakukan dengan menggunakan stopwatch pada proses pengaitan kawat dan proses menginstalasi amplimesh ke splan. Setelah dilakukan perhitungan, waktu baku usulan yang diperoleh untuk membuat 1 amplimesh adalah 2 menit 9 detik, sehingga produktivitas perusahaan mencapai $61 \%$, dan peningkatan kapasitas produksi sebanyak 39,38\% atau sebanyak 55 amplimesh pershiftnya.
\end{abstract}

Kata Kunci: Time Study, Waktu Baku, Jam Henti, Kapasitas Produksi.

\section{PENDAHULUAN}

Perkembangan teknologi yang semakin maju membawa dampak yang luar biasa pada berbagai bidang, baik industri manufaktur maupun jasa. Perusahaan yang bergerak di bidang industri tersebut harus siap untuk menghadapi tingginya tingkat persaingan jika mereka ingin tetap bertahan dan dapat terus meningktakan keuntungan yang diperoleh (Kumar, 2006).

PT. AE merupakan produsen fabrikasi dan ekstrusi profil alumunium terkemuka di indonesia dengan berbagai fasilitas manufaktur untuk ekstrusi alumunium, fabrikasi, clear anodize, anodisasi warna dan powder coating dimana alakasa mewarisi sistem manajemen dan teknologi dariAlcan Alumunium (Alcan) Canada melalui kolaborasi hubungan usaha dengan Alcan dari tahun 1972 hingga tahun 1988.

Dalam rangka meningkatkan kapasitas produksi, PT. AE menerapkan target waktu penyelesaian suatu komponen. Maka dari itu, perusahaan saat ini membutuhkan perhitungan waktu baku dalam penyelesaian proses racking produk amplimesh. Karena dengan adanya waktu baku proses di dalam suatu perusahaan, maka lama waktu yang digunakan untuk menyelesaikan produksi di dalam suatu perusahaan bisa seragam dan sama.

Operator yang cakap, terampil, dan rajin akan menyelesaikan satu unit produk dalam jangka waktu yang tepat sesuai dengan waktu baku yang telah ditetapkan oleh perusahaan. Operator yang kurang cakap akan menyelesaikan pekerjaan yang sama, namun dengan waktu yang lebih panjang. Keadaan demikian tentu akan merugikan pihak perusahaan, karena proses produksi menjadi delay, sehingga tidak dapat memberikan jawaban mengenai yang pasti selesainya kepada pelanggan.

Berikut ini adalah jumlah kapasitas produksi perusahaan saat ini pada departemen powder coating.

Tabel 1. Kapasitas produksi amplimesh saat ini.

\begin{tabular}{|c|c|}
\hline Proses & $\begin{array}{c}\text { Kapasitas produksi } \\
\text { amplimesh saat ini }\end{array}$ \\
\hline $\begin{array}{c}\text { Proses racking } \\
\text { amplimesh }\end{array}$ & 140 unit \\
\hline
\end{tabular}

Berdasarkan tabel 1, terlihat jelas bahwa 
PT. AE hanya dapat memproduksi 140 amplimesh sehingga diperlukan adanya perhitungan waktu baku agar kapasitas produksi dapat ditingkatkan. Karena dengan adanya waktu baku yang ditetapkan maka operator bisa bekerja berdasarkan pada waktu baku, sehingga setiap harinya kapasitas produksi dapat menjadi terukur dan stabil.

Bagian racking produk amplimesh pada departemen powder coating adalah bagian produksi yang masih menggunakan tenaga manusia. Apabila salah satu operator pada bagian racking ada yang bekerja secara tidak baik akan menimbulkan berhentinya proses racking pada departemen powder coating. Pengukuran kerja pada dasarnya merupakan suatu usaha untuk menentukan lamanya waktu kerja yang dibutuhkan oleh seorang operator atau pekerja yang sudah terlatih untuk menyelesaikan pekerjaan yang spesifik pada tingkat kecepatan kerja yang normal, dan dalam lingkaran kerja yang terbaik pada saat itu.

Oleh karena itu, perlu dilakukan pengukuran waktu kerja yang akan dilakukan menggunakan metode pengukuran waktu kerja secara langsung dengan jam henti (stopwatch). Metode ini tepat dipakai karena pekerjaan racking merupakan pekerjaan yang berlangsung singkat dan berulangulang.

Untuk mengatasi permasalahan yang telah dipaparkan sebelumnya maka penulis melakukan penelitian usulan penentuan waktu baku proses racking produk ampli-mesh dengan metode jam henti pada departemen powder coating.

\section{a. Asumsi Masalah}

Asumsi yang digunakan: 1) Tingkat kepercayaan 95\% dan tingkat ketelitian 90\%, 2) Faktor penyesuaian yang penilaiannya didasarkan pada cara schumard dan Westinghouse, 3) Faktor kelonggaran, yaitu kelonggaran yang diberikan kepada operator.

\section{LANDASAN TEORI \\ a. Perancangan Sistem Kerja}

Perancangan sistem kerja adalah suatu ilmu yang terdiri dari teknik-teknik dan prinsip-prinsip untuk mendapatkan rancangan terbaik dari sistem kerja yang bersangkutan. Teknik-teknik dan prinsip-prinsip ini digunakan untuk mengatur komponen-komponen sistem kerja yang terdiri dari manusia de- ngan sifat dan kemampuannya, peralatan kerja, bahan serta lingkungan kerja sedemikian rupa sehingga dicapai tingkat efektivitas dan efisiensi yang tinggi bagi perusahaan serta aman, sehat dan nyaman bagi pekerja. Pengukuran kebaikan rancangan sistem kerja dilakukan berdasarkan waktu yang dihabiskan untuk bekerja, beban-beban fisik yang dialami serta akibat-akibat psikologis dan sosiologis yang ditimbulkannya. Perhitungan yang berkaitan dengan ongkos pun kerap dilakukan untuk itu (Wignjosoebroto, 2003).

Telah dikemukakan tadi bahwa perancangan sistem merupakan hasil perpaduan antara teknik-teknik pengukuran waktu dan prinsip-prinsip studi gerakan sebagaimana dikembangkan oleh para pemulanya. Dalam perkembangan selanjutya pun ciri masingmasing tetap ada walaupun dalam cakupan yang lebih luas. Walaupun tidak hanya pengukuran waktu, pengukuran-pengukuran tetap dilakukan dengan teknik-teknik pengukurannya (Sutalaksana, 2006).

\section{b. Pengukuran Waktu Kerja}

Menurut Iftikar Z. Sutalaksana dkk (2006), pengukuran waktu baku dibagi kedalam dua bagian, yaitu secara langsung dan tidak langsung. Pengukuran secara langsung maksudnya adalah pengukuran dilakukan di tempat di mana pengukuran tersebut dilaksanakan seperti cara jam berhenti dan sampling pekerjaan. Pengukuran cara kedua adalah tidak langsung yaitu dilakukan tanpa harus berada di tempat pekerjaan. Cara tersebut dilakukan dengan membaca tabel-tabel yang tersedia asalkan mengetahui jalannya pekerjaan melalui elemen-elemen pekerjaan atau gerakan seperti data waktu baku dan data gerakan.

Penelitian kerja dan analisa kerja memusatkan perhatian kepada bagaimana suatu macam pekerjaan akan diselesaikan. Pengaplikasian prinsip dan teknik pengukuran cara kerja yang optimal dalam sistem kerja akan diperoleh alternatif metode pelaksanaan kerja yang efektif dan efisien. Kerja dikatakan efisien apabila waktu penyelesaian berlangsung singkat. Untuk menghitung waktu (standar time) penyelesaian pekerjaan maka perlu diterapkan prinsip-prinsip dan teknik pengukuran kerja. Pengukuran kerja adalah suatu metode penetapan keseimbangan antara kegiatan manusia dikontri- 
busikan dengan unit output yang dihasilkan.

Waktu baku diperlukan terutama untuk perencanaan kebutuhan tertentu tenaga kerja (man power planning), estimasi biaya-biaya untuk upah karyawan, penjadwalan produksi dan penganggaran, perencanaan sistem, pemberian bonus bagi karyawan yang berprestasi, indikasi output yang mampu dihasilkan oleh seorang operator.

Teknik pengukuran waktu kerja dapat dibagi menjadi 2, yaitu: 1) Pengukuran secara langsung maksudnya adalah pengukuran dilakukan ditempat dimana pengukuran tersebut dilaksanakan seperti cara jam berhenti dan sampling pekerjaan, 2) Pengukuran tidak langsung yaitu dilakukan tanpa harus berada ditempat pekerjaan. Cara tersebut dilakukan dengan membaca tabel-tabel yang tersedia asalkan mengetahui jalannya pekerjaan melalui elemen-elemen pekerjaan atau gerakan seperti data waktu baku dan data gerakan.

\section{c. Waktu siklus}

Waktu siklus adalah waktu yang digunakan dalam melakukan suatu elemen kerja tanpa mempertimbangkan aspek kecepatan kerja dan kelonggaran. Data waktu siklus diambil sebanyak 60 sampel kemudian diolah agar didapatkan nilai rata-rata waktu siklus. Untuk menghitung waktu siklus, rumusnya seperti berikut:

$\bar{x}=\frac{\sum x_{i . n}}{\sum \text { Sub grup }}$

Dimana:

$\sum \mathrm{x}=$ Jumlah rata - rata data sampel

$\sum$ subgrup $=$ Jumlah rata rata dari sub grup

$\mathrm{x} \square \quad=$ rata - rata waktu siklus

\section{d. Uji statistik}

Uji statistik diperlukan untuk menganalisa apakah data sampel waktu yang diolah sudah mencukupi dan sudah seragam. Uji statistik terdiri dari uji normal. Uji kecukupan data dan uji keseragaman data, seperti dikatakan oleh Iftikar Z Sutalaksana,dkk (2006)

\section{e. Uji Kecukupan:}

$\mathrm{N}^{\prime}=\left[\frac{k}{S} \cdot \frac{\sqrt{N \cdot \sum\left(X i^{2}\right)-\left(\sum X i\right)^{2}}}{\sum X i}\right]^{2}$

Dimana:

$\mathrm{N}^{\prime}$ = Jumlah pengamatan yang harusnya dilakukan

$\mathrm{k} \quad=$ Tingkat kepercayaan dalam pengamatan.
Jika tingkat keyakinan 99\%, maka $\mathrm{k}=2,58 \sim 3$

Jika tingkat keyakinan 95\%, maka $\mathrm{k}=1,96 \sim 2$

Jika tingkat keyakinan 68\%, maka $\mathrm{k}=1$

$\mathrm{s}=$ Derajat ketelitian dalam pengamatan.

$\mathrm{N}$ = jumlah pengamatan yang sudah dilakukan

$\mathrm{Xi}=$ Data pengamatan

\section{f. Uji keseragaman:}

$\sigma=\sqrt{\frac{\sum\left((X i-\overline{\bar{X}})^{2}\right)}{N-1}}$

Dimana:

$\Sigma \quad=$ Jumlah sampel yang dihitung dalam pengamatan

$\mathrm{Xi}=$ Data pengamatan

$\overline{\bar{x}} \quad=$ Jumlah rata-rata dari sub grup

$\mathrm{N} \quad=$ Jumlah pengamatan yang sudah dilakukan

\section{g. Waktu normal}

Waktu normal dihitung dengan cara perkalian antara faktor penyesuaian dengan nilai rata-rata waktu siklus. Metode penyesuaian yang -digunakan dalam penghitungan waktu normal proses racking pada amplimesh adalah metode Schumard dan Westinghouse.

$\mathrm{P} \quad=\mathrm{P} 1 \mathrm{XP} 2$

$\mathrm{Wn}=\mathrm{Ws} \times \mathrm{P}$

Dimana:

$\mathrm{Wn}=$ Waktu normal

Ws $\quad$ Waktu siklus

$\mathrm{P} \quad=$ Faktor penyesuaian

P1 = Penyesuaian cara schumard

$\mathrm{P} 2=$ Penyesuaian cara westinghouse

\section{h. Waktu baku}

Waktu baku adalah waktu yang diperlukan oleh manusia untuk menyelesaikan suatu pekerjaan secara tuntas. Waktu baku sudah mempertimbangkan aspek kecepatan kerja operator dan kelonggaran yang dibutuhkan oleh operator.

$\mathrm{Wb}=\mathrm{Wn} \times(1+A)$

Dimana:

$\mathrm{Wn}=$ Waktu normal

$\mathrm{A} \quad=$ Kelonggaran

\section{i. Menentukan faktor penyesuaian}

Cara pertama adalah cara presentase yang merupakan cara yang paling awal digunakan dalam melakukan penyesuaian. Di sini besarnya faktor penyesuaian sepenuhnya ditentukan oleh pengukur melalui pengama- 
tannya selama melakukan pengukuran. Jadi sesuai dengan yang terlihat selama pengukuran dia menentukan harga $\mathrm{p}$ yang menurut pendapatnya akan menghasilkan waktu normal bila harga ini dikalikan dengan waktu siklus. Terlihat bahwa penyesuaiannya dilakukan dengan cara yang sangat sederhana. namun segera terlihat pula adanya kekurangan ketelitian sebagai akibat dari "kasarnya" cara penilaian. Bertolak dari kelemahan ini dikembangkanlah cara-cara lain yang dipandang sebagai cara lain yang lebih objektif. Cara-cara ini umumnya memberi "patokan" yang dimaksudkan untuk mengarahkan penilaian pengukur terhadap kerja operator. Dua cara akan diperhasilkan disini , yaitu cara schumard dan westinghouse.

Cara schumard memberi patokan-patokan penilaian melalui kelas-kelas kinerja kerja dengan setiap kelas mempunyai nilai sendiri-sendiri. Disini patokan penilaian melalui kelas-kelas superfast, fast + , fast , fast - , excellent dan seterusnya.

Table 2. Faktor Penyesuaian.

\begin{tabular}{|l|l|}
\hline \multicolumn{1}{|c|}{ Kelas } & Penyesuaian \\
\hline Good - & 65 \\
\hline Normal & 60 \\
\hline Fair + & 55 \\
\hline Fair & 50 \\
\hline Fair - & 45 \\
\hline Poor & 40 \\
\hline
\end{tabular}

Sumber: Sutalaksana (2006)

Tabel 3 Penyesuaian Cara Schumard.

\begin{tabular}{|l|l|}
\hline \multicolumn{1}{|c|}{ Kelas } & Penyesuaian \\
\hline Superfast & 100 \\
\hline Fast + & 95 \\
\hline Fast & 90 \\
\hline Fast - & 85 \\
\hline Excellent & 80 \\
\hline Good + & 75 \\
\hline Good & 70 \\
\hline
\end{tabular}

Sumber: Sutalaksana (2006).

Berbeda dengan cara schumard diatas, cara westinghouse mengarahkan penilaian kepada 4 faktor yang dianggap menentukan kewajaran atau ketidakwajaran dalam bekerja. Yaitu keterampilan, usaha, kondisi kerja, dan konsistensi. Setiap faktor terbagi dalam kelas-kelas dengan nilainya masing-masing keterampilan didefinisikan sebagai kemampuan mengikuti cara kerja yang ditetapkan.
Latihan dapat meningkatkan keterampilan tetapi hanya sampai ke tingkat tertentu saja, tingkat yang merupakan kemampuan maksimal yang dapat diberikan pekerja yang bersangkutan.

Keterampilan juga dapat menurun, yaitu bila terlampau lama tidak menangani pekerjaan tersebut. Atau karena sebab-sebab lain seperti kerena kesehatan yang terganggu, rasa fatique yang berlebihan, pengaruh lingkungan sosial dan sebagainya. Keterampilan dibagi kedalam 6 kelas yaitu:
1. Super skill
2. Excellent skill
3. Good skill
4. Average skill
5. Fair skill
6. Poor skill

Untuk usaha atau effort cara westinghouse membagi juga kelas-kelas dengan ciriciri tersendiri. Yang dimaksud usaha disini adalah kesungguhan yang ditunjukkan atau diberikan operator ketika melakukan pekerjaannya. Usaha juga dibagi dalam 6 kelas seperti keterampilan.

Yang dimaksud kondisi kerja pada cara westinghouse adalah kondisi fisik lingkungannya seperti keadaan, pencahayaan, suhu dan kebisingan ruangan. Bila 3 faktor lainnya, yaitu keterampilan, usaha dan konsistensi merupakan sesuatu yang dicerminkan operator. Maka kondisi kerja merupakan sesuatu diluar operator yang diterima apa adanya oleh operator tanpa banyak kemampuan mengubahnya.

Faktor lain yang harus diperhatikan ialah konsistensi, faktor ini perlu diperhatikan karena pada setiap pengukuran waktu angka-angka yang dicatat tidak pernah semuanya sama, waktu penyelesaian yang ditunjukan pekerja selalu berubah-ubah dari satu siklus ke siklus lainnya, dari jam ke jam bahkan dari hari ke hari. Selama masih dalam batas kewajaran masalah ini tidak akan timbul, tetapi jika variabilitasnya tinggi maka hal tersebut harus diperhatikan. 
Tabel 4. penyesuaian westinghouse.

\begin{tabular}{|c|c|c|c|}
\hline$F^{2}=1+a r$ & Kelas & Lambeng & Penryesuaian \\
\hline Keterampilan & $\begin{array}{l}\text { Super skill } \\
\text { Exceilent } \\
\text { Good } \\
\text { Average } \\
\text { Fair } \\
\text { Poor }\end{array}$ & $\begin{array}{l}A 1 \\
A 2 \\
B 1 \\
B 2 \\
C 1 \\
C 2 \\
D \\
\text { E1 } \\
\text { E2 } \\
\text { F1 } \\
\text { F2 }\end{array}$ & $\begin{array}{l}-0,15 \\
-0,13 \\
-0,11 \\
-0,08 \\
-0,06 \\
-0.03 \\
0,00 \\
-0,05 \\
-0,10 \\
-0,16 \\
-0,22\end{array}$ \\
\hline Usaha & $\begin{array}{l}\text { Excessive } \\
\text { Excellent } \\
\text { Good } \\
\text { Awerage } \\
\text { Fair } \\
\text { Poor }\end{array}$ & $\begin{array}{l}\text { A1 } \\
\text { A2 } \\
\text { B1 } \\
\text { B2 } \\
\text { C1 } \\
\text { C2 } \\
\text { D } \\
\text { E1 } \\
\text { E2 } \\
\text { F1 } \\
\text { F2 }\end{array}$ & $\begin{array}{l}-0,13 \\
-0,12 \\
-0,10 \\
-0,08 \\
-0,05 \\
-0.02 \\
0,00 \\
-0,04 \\
-0,08 \\
-0,12 \\
-0,17\end{array}$ \\
\hline Kondisi kerja & $\begin{array}{l}\text { Ideal } \\
\text { Excellent } \\
\text { Good } \\
\text { Average } \\
\text { Fair } \\
\text { Poor }\end{array}$ & $\begin{array}{l}A \\
B \\
C \\
\text { D } \\
\text { E } \\
\text { F }\end{array}$ & $\begin{array}{l}-0,05 \\
-0,04 \\
-0,02 \\
0,00 \\
-0.03 \\
-0,07\end{array}$ \\
\hline Konsistensi & $\begin{array}{l}\text { Perfect } \\
\text { Excellent } \\
\text { Good } \\
\text { Average } \\
\text { Fair } \\
\text { Poor }\end{array}$ & $\begin{array}{l}\text { A } \\
\text { B } \\
\text { C } \\
\text { D } \\
\text { E } \\
\text { F }\end{array}$ & $\begin{array}{l}-0,04 \\
-0,03 \\
-0,01 \\
0,00 \\
-0,02 \\
-0,04\end{array}$ \\
\hline
\end{tabular}

Sumber: Sutalaksana (2006)

\section{j. Kelonggaran}

Salah satu hal yang paling penting di perhatikan dalam pengukuran waktu adalah faktor kelonggaran. faktor kelonggaran ini ditambahkan pada waktu normal yang telah didapatkan. Kelonggaran diberikan untuk tiga hal yaitu:

1) kelonggaran untuk kebu-tuhan pribadi. Yang termasuk dalam kebu-tuhan pribadi disini adalah hal hal seperti minum sekedarnya untuk menghilangkan haus, ke kamar kecil, bercakap dengan teman sekerja sekedarnya. Besarnya kelonggaran yang diberikan untuk kebutuhan pribadi seperti itu berbeda dari satu pekerjaan ke pekerjaan lainnya karena setiap pekerjaan berbeda karakteristiknya. Berdasarkan penelitian ternyata besarnya kelonggaran ini bagi pria dan wanita berbeda. Bagi pria kelong-garannya $2 \%-2,5 \%$, sedangkan untuk wanita 2,5\%-5\%,

2) Kelonggaran untuk menghilang-kan rasa fatique. Rasa fatique biasanya terlihat saat hasil produksi menurun, baik kuantitas maupun kualitas. Jika rasa fatique telah datang dan pekerja dituntut untuk menghasilkan performansi normalnya, maka usaha yang dikeluarkan pekerja lebih besar dan dari normal dam ini menambah rasa fatique. Besarnya kelonggaran ini di perlihat kan pada tabel nantinya.

3) Kelonggaran untuk hambatan hambatan yang tak terhindarkan. Hambatan dalam melaksakan pekerjaan itu ada dua jenisnya, yang pertama hambatan yang dapat dihindarkan dan yang kedua hambatan yang tidak dapat dihindarkan. Beberapa contoh dari hambatan yang tidak dapat dihinarkan adalah, menerima atau meminta petunjuk dari pengawas, melakukan penyesuaian mesin, memperbaiki kemacetan kemacetan singkat, mengasah peralatan potong, mengambil alat alat khusus, hambatan hambatan karena kesalahan pemakaian, mesin mati karena mati listrik. Tabel kelonggaran akan dilampirkan pada lampiran.

\section{c. Powder Coating}

Pelapisan logam adalah suatu cara yang dilakukan untuk memberikan sifat tertentu pada suatu permukaan benda kerja, di mana diharapkan benda tersebut akan mengalami perbaikan baik dalam hal struktur mikro maupun ketahanannya, dan perbaikan terhadap sifat fisiknya. Pelapisan logam merupakan bagian akhir dari proses produksi dari suatu produk. Proses tersebut dilakukan setelah benda kerja mencapai bentuk akhir atau setelah proses pengerjaan mesin serta penghalusan terhadap permukaan benda kerja yang dilakukan. Dengan demikian, proses pelapisan termasuk dalam kategori pekerjaan finishing atau sering juga disebut tahap penyelesaian dari suatu produk.

Korosi adalah kerusakan atau degradasi logam akibat reaksi dengan lingkungan yang korosif. Korosi dapat juga diartikan sebagai serangan yang merusak logam karena logam bereaksi secara kimia dengan lingkungan. Ada definisi lain yang mengatakan bahwa korosi adalah kebalikan dari proses ekstraksi logam dari bijih mineralnya.

Tentunya kita sering melihat bendabenda di sekitar kita dilapisi oleh cat atau coating mulai dari jembatan, tangki, air, mobil, pesawat, baja struktural, kapal, kayu, mabel, blok beton, peralatan listrik, dinding, kaleng pembungkus makanan dan sebagainya. Coating tersebut selain digunakan untuk menambah nilai estetika, juga untuk melin- 
dungi material dari korosi, panas, aus dan sebagainya sehingga menambah umur pemakaian material tersebut. Bahwa untuk tiaptiap jenis material membutuhkan coating yang berbeda, karena itu tahapan pertama yang sangat penting dalam penentuan formulasi coating adalah mengetahui coating itu akan digunakan untuk apa. Mengingat setiap coating bersifat spesifik. Sebagai contoh ialah powder coating yang biasa digunakan untuk pelapisan besi dan alumunium. Keuntungan karena powder coating dapat menjangkau bagian yang terlindungi. Terdapat 2 teknik pengecatan kering (powder coating): 1) Pencelupan ; benda yang akan dilapisi dicelupi kedalam bak yang berisi powder coating yang telah diberikan muatan elektrostatik. 2) Penyemprotan: powder coating yang telah diberi muatan elektrostatik tersebut disemprotkan kepada objek yang akan dilapisi.

Berikut adalah contoh benda yang terbuat dari alumunium dan memakai proses powder coating dalam pewarnaannya.

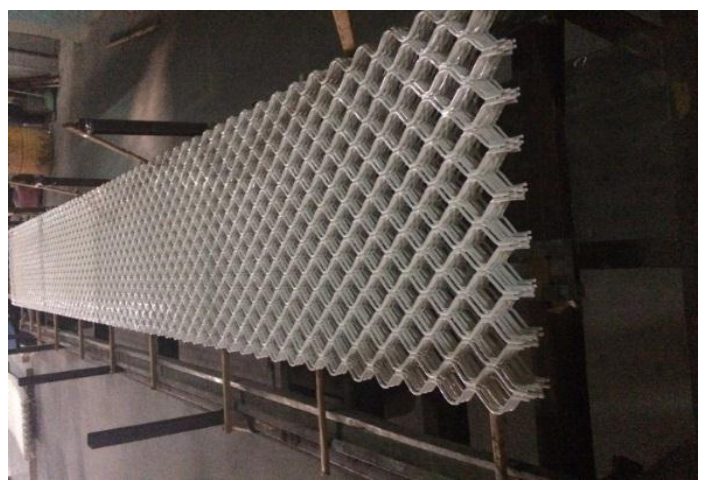

Gambar 1 contoh produk amplimesh.

(Sumber: PT.AE, 2017)

Setelah benda melalui salah satu proses tersebut diatas kemudian benda yang telah terlapisi powder coating dimasukan ke dalam oven, tujuannya untuk melelehkan dan menyatukan partikel sebruk-serbuk sehingga membentuk lapisan-lapisan yang halus melapisi objek atau benda kerja. Terdapat 2 jenis powder coating yang tersedia untuk melapisi permukaan suatu benda kerja: 1) Thermo plastic, material powder ini akan mengalami pencairan jika benda kerja mendapat perlakuan panas, 2) Thermosetting, merupakan bahan yang kuat dan tidak akan mencair lembali walaupun benda kerja mendapatkan perlakuan panas.

\section{METODOLOGI PENELITIAN}

Metode jam henti terdiri dari pengambilan data waktu kerja selama berlangsung kemudian mengolah data pengamatan dengan cara: a) menghitung rata-rata sub grup yang diperoleh dari data pengamatan, b) Menghitung standar deviasi, c) menghitung standar deviasi rata-rata sub grup, d) melakukan uji normalitas data dengan menggunakan aplikasi minitab 17 dengan metode ryan-joiner, e) melakukan uji keseragaman data menggunakan peta kontrol kemudian memplotkan data ke dalam grafik, sehingga dapat diketahui data yang berada di luar batas control, f) Melakukan uji kecukupan data, g) Melakukan perhitungan waktu siklus h) melakukan perhitungan waktu normal, i) melakukan perhitungan waktu baku

Langkah-langkah penelitian ini seperti pada gambar berikut.

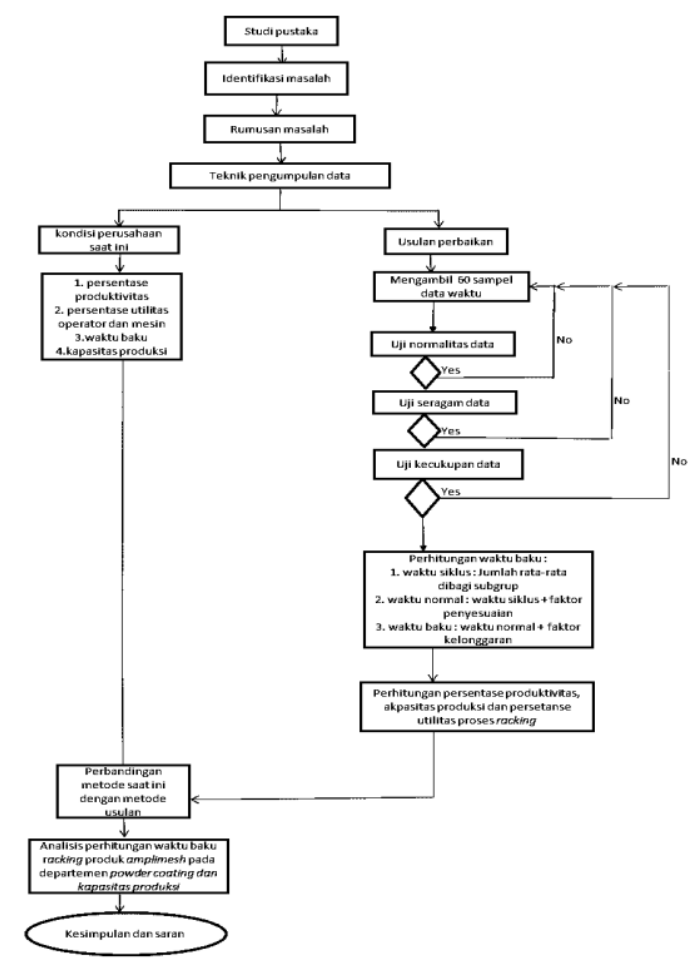

Gambar 1 Diagram Metode Penelitian

\section{PEMBAHASAN}

Pengukuran waktu baku diawali dengan mengambil sampel pekerjaan sebanyak 60 data waktu. Kemudian dilakukan uji statistik, perhitungan waktu siklus, perhitungan waktu normal dan penghitungan waktu baku. Proses racking terbagi menjadi 2 elemen pekerjaan. Elemen pekerjaan tersebut antara lain pengaitan kawat dan instalasi amplimesh ke splan (racking). 


\section{a. Waktu Proses Pengaitan Kawat}

\section{1) Uji Statistik}

Uji statistik diperlukan untuk menganalisa apakah data sampel waktu yang diolah sudah mencukupi dan sudah seragam. Uji statistik terdiri dari uji normalitas data, uji keseragaman data dan uji kecukupan data (Amalia,dkk. 2012). Berikut pengolahan data uji statistik yang dilakukan dalam proses pengaitan kawat. Kesimpulan dari uji statistik: a) Uji normalitas data, menghasilkan kenormalan pada grafik karena pvalue> 0,100 . Maka data dikatakan normal, b) Uji keseragaman data, menghasilkan data yang seragam karena tidak adanya data yang melebihi batas kendali atas (BKA) dan batas kendali bawah (BKB), c) uji kecukupan data, menghasilkan data yang cukup dikarenakan $\mathrm{N}$ ' lebih kecil dari $\mathrm{N}$ (jumlah sampel data yang digunakan)

Dari ketiga uji tersebut maka data bisa di proses untuk ke tahap berikutnya yaitu perhitungan waktu siklus, waktu normal dan waktu baku.

\section{2) Waktu Siklus}

Waktu siklus dihitung dengan cara membagi antara jumlah waktu pengamatan dan jumlah pengamatan yang dilakukan (berapa banyak data sampel yang digunakan). Berikut perhitungan waktu siklus proses pengaitan kawat pada amplimesh:

$$
\begin{aligned}
\mathrm{Ws} & =\frac{\sum x i}{N} \\
& =\frac{281,1}{10} \\
& =28,11 \text { detik }
\end{aligned}
$$

\section{3) Waktu Normal}

Waktu normal dihitung dengan cara perkalian antara faktor penyesuaian dengan nilai rata-rata waktu siklus. Metode penyesuaian yang digunakan dalam penghitungan waktu normal proses pengaitan kawat pada amplimesh adalah metode Schumard dan Westinghouse. Berikut pada tabel 6 dijabarkan faktor penyesuaian yang diberikan untuk proses pengaitan kawat.

Tabel 6 Faktor Penyesuaian proses Pengaitan Kawat.

\begin{tabular}{|c|c|c|}
\hline \multicolumn{3}{|c|}{ Metode Schumard } \\
\hline Kelas & Penyesuaian & P1 \\
\hline Normal & 60 & 1 \\
\hline
\end{tabular}

\begin{tabular}{|c|c|c|c|}
\hline \multicolumn{4}{|c|}{ Metode Westinghouse } \\
\hline Faktor & Kelas & Lambang & Penyesuaian \\
\hline Keterampilan & Good & C1 & 0.06 \\
\hline Usaha & Average & D & 0.00 \\
\hline Kondisi Kerja & Fair & E & -0.03 \\
\hline Konsistensi & Good & C & 0.01 \\
\hline & & P2 & 1,04 \\
\cline { 4 - 4 } & &
\end{tabular}

Tabel 6 pada metode Schumard, dipilih kelas normal. karena operator melakukan pekerjaan dengan kecepatan normal, tanpa tergesa-gesa. Pada metode Westinghouse: (1). Faktor keterampilan tergolong kelas good sebab operator cenderung terampil dalam melakukan perbaikan apabila terjadi kesalahan dalam melakukan pekerjaannya, operator juga sudah terbiasa di bidang tersebut; (2). Faktor usaha masuk ke kelas average sebab operator melakukan pekerjaan dengan kondisi normal tanpa terburu-buru. (3). Faktor kondisi kerja masuk ke kategori fair, sebab operator bekerja di lingkungan yang udaranya mengandung debu dan powder sehingga butuh alat perlindungan, sedangkan alat perlindungan tidak tersedia lengkap di perusahaan. (4). Faktor konsistensi kerja dikategorikan ke dalam kelas good. Sebab operator melakukan pekerjaan dengan waktu yang konsisten.

Nilai waktu normal proses pengaitan kawat dengan faktor penyesuaian sebesar 1,04 adalah 29,23 detik.

Tabel 7. Hasil Perhitungan Waktu Normal Proses Pengaitan Kawat.

\begin{tabular}{|c|c|c|}
\hline & $\begin{array}{c}\text { Faktor } \\
\text { Penyesuaian }\end{array}$ & $\begin{array}{c}\text { Waktu Normal } \\
\text { (detik) }\end{array}$ \\
\cline { 2 - 3 } & $\mathrm{P}=\mathrm{P} 1 * \mathrm{P} 2$ & Wn $=$ Ws*P \\
\hline $\begin{array}{c}\text { Proses } \\
\text { Waktu } \\
\text { Mengaitkan } \\
\text { Kawat }\end{array}$ & 1,04 & 29,23 \\
\hline
\end{tabular}

\section{4) Waktu Baku}

Waktu baku adalah waktu yang diperlukan manusia untuk menyelesaikan suatu pekerjaan secara tuntas. Waktu baku sudah mempertimbangkan aspek kecepatan kerja operator dan kelonggaran yang dibutuhkan oleh operator. Berikut disajikan table 8 untuk menjelaskan nilai kelonggaran yang diberikan kepada operator dalam proses pengaitan kawat untuk proses racking. 
Tabel 8 Nilai Kelonggaran Proses Pengaitan Kawat.

\begin{tabular}{|c|c|c|c|}
\hline \multicolumn{4}{|c|}{ Tabel Nilai Kelonggaran } \\
\hline No & Faktor & Contoh Kelonggaran & Kelonggaran \\
\hline $\mathrm{a}$ & $\begin{array}{l}\text { Tenaga yang } \\
\text { dikeluarkan }\end{array}$ & $\begin{array}{l}\text { Mengaitkan kawat ke } \\
\text { amplimesh }\end{array}$ & $0 \%$ \\
\hline $\mathrm{b}$ & $\begin{array}{l}\text { Sikap kerja } \\
\text { membungkuk }\end{array}$ & $\begin{array}{l}\text { Jongkok bertumpu pada } 2 \\
\text { kaki }\end{array}$ & $5 \%$ \\
\hline $\mathrm{c}$ & $\begin{array}{l}\text { Gerakan kerja } \\
\text { nomal }\end{array}$ & Pengaitan gerakan bebas & $0 \%$ \\
\hline $\mathrm{d}$ & $\begin{array}{l}\text { Kelelahan mata } \\
\text { pandangan yang } \\
\text { hampir terus- } \\
\text { menerus }\end{array}$ & $\begin{array}{l}\text { Mengaitkan kawat pada } \\
\text { amplimesh }\end{array}$ & $6 \%$ \\
\hline $\mathrm{e}$ & $\begin{array}{l}\text { Keadaan } \\
\text { temperatur tempat } \\
\text { kerja normal }\end{array}$ & Suhu sekitar 22-28 & $5 \%$ \\
\hline f & $\begin{array}{l}\text { Keadaan atmosfer } \\
\text { kurang baik }\end{array}$ & $\begin{array}{l}\text { Ada bau beracun, atau } \\
\text { tidak beracun tapi banyak }\end{array}$ & $7 \%$ \\
\hline g & $\begin{array}{l}\text { Keadaan } \\
\text { lingkungan yang } \\
\text { baik siklus kerja } \\
\text { berulang }\end{array}$ & $\begin{array}{l}\text { Pengikatan kawat pada } \\
\text { amplimesh }\end{array}$ & $0 \%$ \\
\hline $\mathrm{h}$ & $\begin{array}{l}\text { Kelonggaran } \\
\text { pribadi }\end{array}$ & \begin{tabular}{|l} 
Pergi ke toilet \\
\end{tabular} & $1 \%$ \\
\hline i & $\begin{array}{l}\text { Hambatan tak } \\
\text { terhindarkan }\end{array}$ & - & $1 \%$ \\
\hline & & Jumlah & $23 \%$ \\
\hline & & Allowance & 0,23 \\
\hline
\end{tabular}

Dari tabel 8:

a) Tenaga yang dikeluarkan (mengaitkan kawat ke amplimesh) diberi 0\% karena pekerjaan mengaitkan kawat tergolong dapat diabaikan dan posisi bekerjanya duduk dan tidak ada beban.

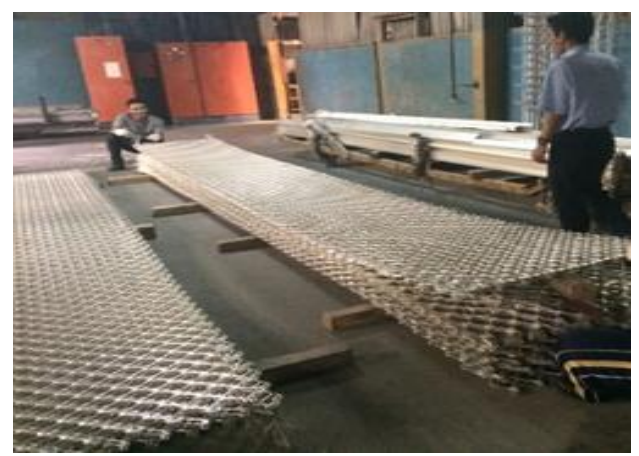

Gambar 2. Proses mengaitkan kawat pada amplimesh

b) Sikap kerja membungkuk (jongkok bertumpu pada 2 kaki) sehingga nilai kelonggaran yang diberikan sebesar 5\% karena posisi operator dalam melakukan pekerjaan membungkuk dan bertumpu pada 2 kaki.

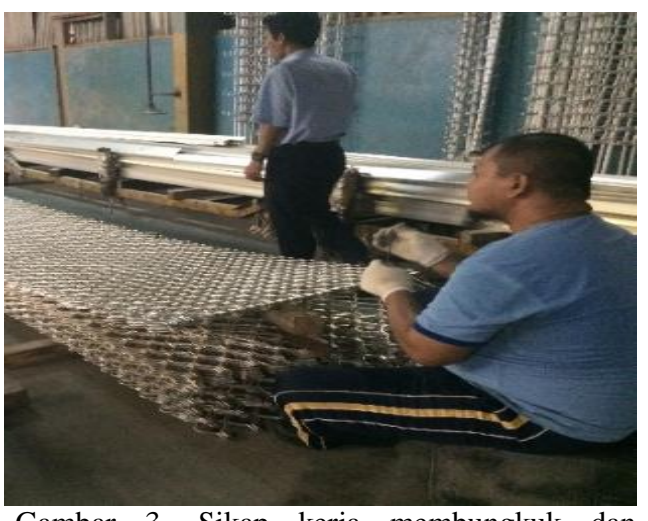

Gambar 3. Sikap kerja membungkuk dan bertumpu pada 2 kaki

c) Gerakan kerja normal (Pengaitan gerakan bebas). Operator bebas menggunakan caranya masing-masing. Sehing-ga termasuk ke dalam kategori gerakan kerja normal tergolong bebas. Sehingga nilai kelonggaran yang diberikan $0 \%$,

d) Kelelahan mata (pandangan yang hampir terus-menerus). Faktor kelonggarannya kelelahan mata dengan pan-dangan yang hampir terus-menerus, karena mengaitkan kawat amplimesh merupakan pekerjaan yang harus teliti, tidak boleh salah mengaitkan kawat karna nanti hasilnya akan ada kawat yang berlebih ataupun kurang.

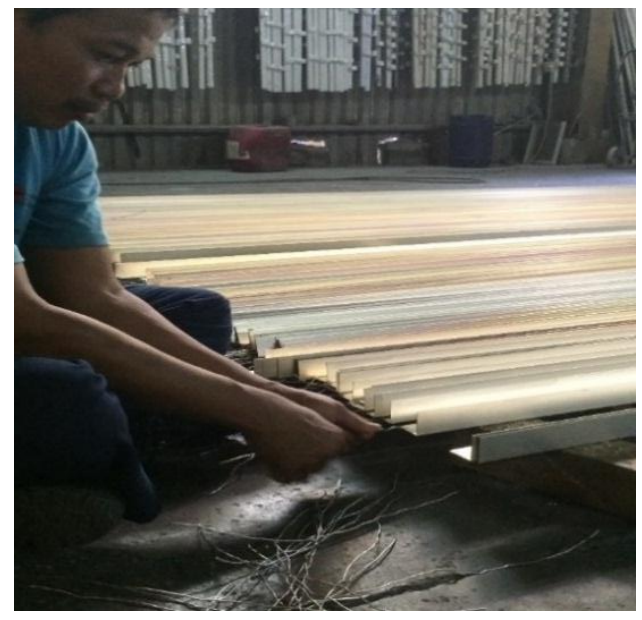

Gambar 4 Pengaitan kawat pada amplimesh.

a) Keadaan suhu tempat kerja normal. Karena suhu sekitar $22-28^{\circ} \mathrm{C}$, Sehingga nilai kelonggaran yang diberikan sebesar $5 \%$

b) Keadaan atmosfer kurang baik karena terdapat banyak debu-debu beracun akibat powder pewarnaan di departemen powder coating dan terhitung banyak pada amplimesh. Sehingga nilai kelonggaran yang diberikan sebesar $7 \%$. 
c) Keadaan lingkungan yang baik (siklus kerja berulang). Sehingga nilai kelonggaran yang diberikan hanya $0 \%$ saja.

d) Kelonggaran untuk kebutuhan pribadi (laki-laki). Faktor kelonggaran untuk kebutuhan pribadi adalah pergi ke toilet dan hanya diberikan nilai sebesar $1 \%$.

e) Kelonggaran hambatan yang tak terhindarkan karena dalam proses racking tidak begitu banyak adanya hambatan, karena dalam prosesnya dilakukan secara manual.

Setelah didapatkan nilai kelonggaran sesuai dengan kondisi operator, maka dilanjutkan dengan perhitungan nilai waktu baku.

Setelah melakukan perhitungan, maka didapatkan hasil waktu baku untuk proses pengaitan kawat pada amplimesh sebesar 35,95 detik. Berikut dapat dilihat tabel 9 sebagai tabel kesimpulan dari perhitungan waktu baku.

Tabel 9. Rekapitulasi Perhitungan Waktu Baku Pengaitan Kawat.

\begin{tabular}{|c|r|}
\hline \multicolumn{2}{|c|}{ Waktu Baku (detik) } \\
\hline $\mathrm{Ws}$ & 28,11 \\
\hline $\mathrm{Wn}$ & 29,23 \\
\hline $\mathrm{Wb}$ & 35,95 \\
\hline
\end{tabular}

\section{b. Waktu Proses Instalasi Amplimesh ke Splan}

1) Waktu Siklus

Berikut perhitungan waktu siklus proses pengaitan kawat pada amplimesh:

$$
\text { Ws } \begin{aligned}
& =\frac{\sum x i}{N} \ldots \ldots \ldots \ldots . . . . . \\
& =\frac{\mathbf{5 1 6 , 2}}{\mathbf{1 0}} \\
& =51,62 \text { detik }
\end{aligned}
$$

\section{2) Waktu Normal}

Berikut pada tabel 10 faktor penyesuaian yang diberikan untuk proses instalasi amplimesh.

\begin{tabular}{|c|c|c|c|}
\hline \multicolumn{4}{|c|}{ Metode Westinghouse } \\
\hline Faktor & Kelas & Lambang & Penyesuaian \\
\hline Keterampilan & Good & $\mathrm{C} 1$ & 0.06 \\
\hline Usaha & Good & $\mathrm{C} 2$ & 0.02 \\
\hline $\begin{array}{c}\text { Kondisi } \\
\text { Kerja }\end{array}$ & Fair & $\mathrm{E}$ & -0.03 \\
\hline Konsistensi & Average & $\mathrm{D}$ & 0 \\
\hline & & $\mathrm{P} 2$ & 1,05 \\
\hline
\end{tabular}

Tabel 10 Faktor Penyesuaian Proses racking.

\begin{tabular}{|c|c|c|}
\hline \multicolumn{3}{|c|}{ Metode Schumard } \\
\hline Kelas & Penyesuaian & P1 \\
\hline Good + & 75 & 1,25 \\
\hline
\end{tabular}

a) Pada metode Schumard, dipilih kelas Good+, karena operator melakukan pekerjaan dengan cepat dan terampil, tanpa tergesa-gesa.

b) Pada metode Westinghouse:

1. Faktor keterampilan tergolong kelas good sebab kualitas hasilnya baik dan dapat memberi petunjukpetunjuk pada pekerja lain serta tidak memerlukan banyak pengawasan sehingga diberikan lambang C1 dengan nilai penyesuaian 0,06 .

2 Faktor usaha masuk ke kelas good sebab operator bekerjanya stabil, gerakan-gerakannya terkoordinasi dengan baik dan gerakannya pun juga cepat. Sehingga diberikan lambing C2 dengan nilai penyesuaian 0,02 .

3. Faktor kondisi kerja masuk ke kategori fair, sebab operator bekerja di lingkungan yang udaranya mengandung debu dan powder sehingga butuh alat perlindungan, sedangkan alat perlindungan tidak tersedia lengkap di perusahaan. Sehingga diberikan lambang E dengan nilai penyesuaian $-0,03$.

Faktor konsistensi kerja dikategorikan ke dalam kelas average. Sebab operator melakukan pekerjaan dengan waktu yang konsisten. Sehingga diberikan lambang D dengan nilai penyesuaian sebesar 0,00 .

Nilai waktu normal proses racking dengan faktor penyesuaian sebesar 1,31 adalah 67,62 detik. Pada tabel 11 dapat dilihat rekapitulasi hasil perhitungan waktu normal. 
Tabel 11 Hasil Perhitungan Waktu Normal Proses Racking.

\begin{tabular}{|c|c|c|}
\hline & $\begin{array}{c}\text { Faktor } \\
\text { penyesuaian }\end{array}$ & $\begin{array}{c}\text { Waktu Normal } \\
\text { (detik) }\end{array}$ \\
\cline { 2 - 3 } & $\mathrm{P}=\mathrm{P} 1 * \mathrm{P} 2$ & $\mathrm{Wn}=\mathrm{Ws} * \mathrm{P}$ \\
\hline $\begin{array}{c}\text { Proses waktu } \\
\text { mengaitkan } \\
\text { kawat }\end{array}$ & 1,31 & 67,62 \\
\hline
\end{tabular}

\section{3) Waktu Baku}

Berikut table 12 untuk menjelaskan nilai kelonggaran yang diberikan kepada operator dalam proses racking.

Tabel 12 Nilai Kelonggaran Proses racking.

\begin{tabular}{|c|c|c|c|}
\hline \multicolumn{4}{|c|}{ Tabel Nilai Kelonggaran } \\
\hline No & Faktor & Contoh kelonggaran & Kelonggaran \\
\hline $\mathrm{A}$ & $\begin{array}{l}\text { Tenaga yang } \\
\text { dikeluarkan } \\
\text { sedang }\end{array}$ & $\begin{array}{l}\text { Mengangkat dan } \\
\text { memasang amplimesh } \\
\text { ke splan }\end{array}$ & $13 \%$ \\
\hline B & $\begin{array}{l}\text { Sikap kerja } \\
\text { berdiri di atas } 2 \\
\text { kaki }\end{array}$ & $\begin{array}{l}\text { Badan tegak memasang } \\
\text { amplimesh ke splan }\end{array}$ & $1,5 \%$ \\
\hline $\mathrm{C}$ & $\begin{array}{l}\text { Gerakan kerja } \\
\text { pada anggota } \\
\text { badan terbatas }\end{array}$ & $\begin{array}{l}\text { Mengangkat dan } \\
\text { memasang sehingga } \\
\text { bekerja dengan tangan } \\
\text { diatas kepala }\end{array}$ & $5 \%$ \\
\hline D & $\begin{array}{l}\text { Kelelahan mata } \\
\text { pandangan } \\
\text { hampir terus } \\
\text { menerus }\end{array}$ & $\begin{array}{l}\text { Memastikan kawat } \\
\text { amplimesh terpasang } \\
\text { dengan baik }\end{array}$ & $6 \%$ \\
\hline$E$ & $\begin{array}{l}\text { Keadaan } \\
\text { temperatur } \\
\text { tempat kerja } \\
\text { normal } \\
\end{array}$ & Suhu sekitar 22-28 & $3 \%$ \\
\hline $\mathrm{F}$ & $\begin{array}{l}\text { Keadaan } \\
\text { atmosfer } \\
\text { kurang baik }\end{array}$ & $\begin{array}{l}\text { Ada bau beracun, atau } \\
\text { tidak beracun tapi } \\
\text { banyak }\end{array}$ & $7 \%$ \\
\hline $\mathrm{G}$ & $\begin{array}{l}\text { Keadaan } \\
\text { lingkungan } \\
\text { yang baik } \\
\text { siklus kerja } \\
\text { berulang }\end{array}$ & $\begin{array}{l}\text { Instalasi amplimesh ke } \\
\text { splan }\end{array}$ & $0 \%$ \\
\hline $\mathrm{H}$ & $\begin{array}{l}\text { Kelonggaran } \\
\text { pribadi }\end{array}$ & Pergi ke toilet & $1 \%$ \\
\hline I & $\begin{array}{l}\text { Hambatan tak } \\
\text { terhindarkan }\end{array}$ & - & $1 \%$ \\
\hline & & Jumlah & $37,5 \%$ \\
\hline & & Allowance & 0,37 \\
\hline
\end{tabular}

1. Tenaga yang dikeluarkan sedang (mengangkat dan memasang amplimesh ke splan) karena tenaga yang dikeluarkan untuk mengangkat amplimesh dan memasangnya ke splan termasuk lumayan, maka nilai kelonggaran yang diberikan sebesar $13 \%$.

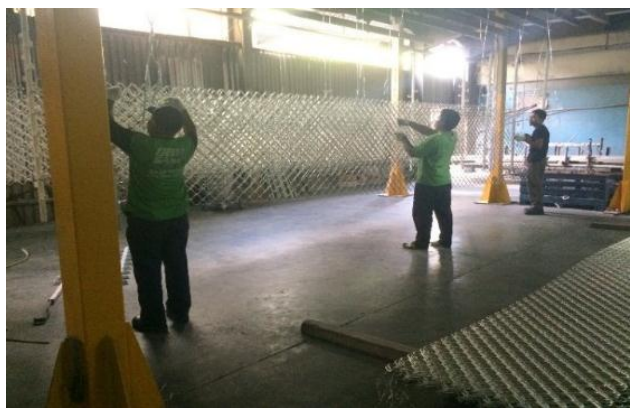

Gambar 5 proses mengangkat dan memasang ampli-mesh pada splan

2. Sikap kerja berdiri diatas 2 kaki (badan tegak memasang amplimesh ke splan). Nilai kelonggaran yang diberikan sebesar $1,5 \%$.

3. Gerakan kerja pada anggota-anggota badan terbatas (bekerja dengan tanaga diatas kepala) Nilai kelonggaran yang diberikan sebesar 5\% karena jaraknya tidak terlalu jauh dan tidak terlalu sulit.

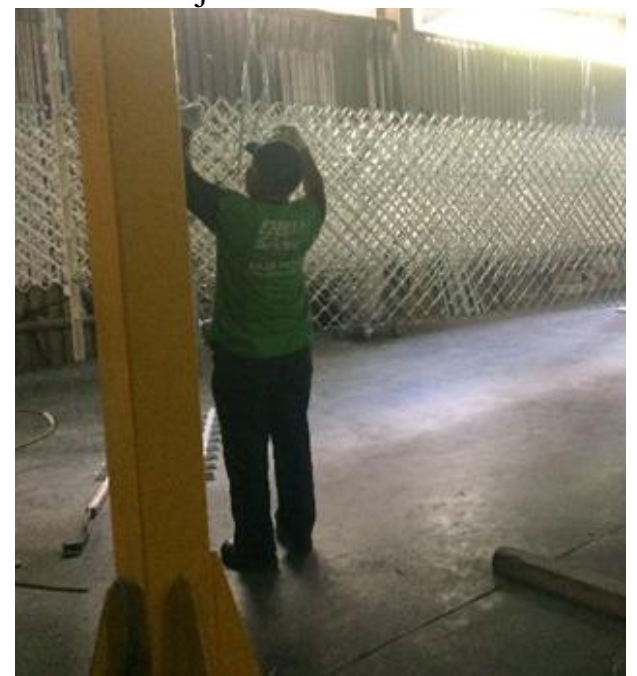

Gambar 6 Sikap kerja berdiri tegak dan ditumpu pada 2 kaki.

4. Kelelahan mata (pandangan yang hampir terus-menerus). Nilai kelonggaran yang diberikan sebesar 6\% karena pencahayaan baik.

5. Keadaan suhu tempat kerja normal sekitar $22-28^{\circ} \mathrm{C}$. Sehingga nilai kelonggaran yang diberikan sebesar 3\%

6. Keadaan atmosfer kurang baik karena terdapat banyak debu-debu beracun akibat powder pewarnaan di departemen powder coating dan terhitung banyak pada amplimesh. Sehingga nilai kelonggaran yang diberikan sebesar $7 \%$.

7. Keadaan lingkungan yang baik (siklus kerja berulang). Karena proses instalasi amplimesh dilakukan secara berulang- 
ulang dalam proses racking. Sehingga nilai kelonggaran yang diberikan hanya $0 \%$ saja.

8. Kelonggaran untuk kebutuhan pribadi (laki-laki) ialah pergi ke toilet dan hanya diberikan nilai sebesar $1 \%$.

9. Kelonggaran hambatan yang tak terhindarkan. Hambatan yang tak terhindarkan diberi nilai kelonggaran $1 \%$ karena dalam proses racking tidak begitu banyak adanya hambatan.

Setelah melakukan penghitungan, maka didapatkan hasil waktu baku untuk proses racking pada amplimesh sebesar 92,64 detik.

Tabel 13 Rekapitulasi Penghitungan Waktu Baku Proses racking.

\begin{tabular}{|c|r|}
\hline \multicolumn{2}{|c|}{ Waktu baku (detik) } \\
\hline $\mathrm{Ws}$ & 51,62 \\
\hline $\mathrm{Wn}$ & 67,62 \\
\hline $\mathrm{Wb}$ & 92,64 \\
\hline
\end{tabular}

Kesimpulan dari proses penghitungan waktu baku untuk proses racking produk amplimesh di departemen powder coating adalah 128,59 atau 129 detik. Sehingga apabila proses racking dilakukan satu per satu maka setiap profil amplimesh dapat diselesaikan selama 2 menit 9 detik.

\section{KESIMPULAN DAN SARAN \\ a. Kesimpulan}

Berdasarkan analisa perhitungan waktu baku yang telah dilakukan, maka dapat ditarik beberapa kesimpulan yaitu: 1) Kapasitas produksi sebelum adanya waktu baku hanya 140 amplimesh, setelah dihitungnya waktu baku mengalami peningkatan menjadi 195 amplimesh atau sebesar $39,52 \%, 2$ ) Untuk membuat 1 buah produk amplimesh pada proses racking departemen powder coating. membutuhkan waktu baku sebanyak 2 menit 9 detik.

\section{b. Saran}

Setelah penulis melakukan penelitian ini maka dapat diberikan saran sebagai berikut:

1) Perhitungan waktu baku dalam proses racking sebaiknya menggunakan usulan perbaikan yang telah dilakukan, karena dapat meningkatkan kapasitas produksi setiap harinya; dan
2) Menciptakan lingkungan kerja yang bersih, nyaman, dengan penerangan yang baik, serta menyediakan perangkat keselamatan kerja dengan lengkap sebagai bentuk kepedulian perusahaan terhadap kondisi kerja karyawan sehingga mampu meningkatkan performansi karyawan.

Melakukan perhitungan waktu standar proses lain yang belum memiliki waktu standar.

\section{DAFTAR PUSTAKA}

Amalia, D.F.,dkk. 2012 “Jurnal Analisis perhitungan waktu baku pada mesin bubut tipe C6232B1menggunakan metode jam henti dimachinery and tool unit PT. Mega andalan kalasan". FKIP, UNS. Surakarta

Kumar, S.A., 2006. "Production and Operation Management". New Age International. New Delhi. Hal. 8-15..

Rinawati, D.I.,dkk. 2012 “Jurnal Penentuan waktu standar dan jumlah tenaga kerja optimal pada produksi batik cap". Undip, Semarang 7(3), 143-150

Sutalaksana, I.Z., 2006. "Teknik Perancangan Sistem Kerja”. Institut Teknologi Bandung, Bandung.

Wignjosoebroto, S., 2003. "Teknik Tata Cara dan Pengukuran Kerja". Guna Widya, Surabaya. Hal. 169-180. 